\title{
Moving Towards Equal Pay for Professional FeMale ATHLETES: WHAT WE CAN LEARN FROM Equal Pay Legislation In ICEland
}

\section{CARRIE PERRAs}

Equal pay legislation has existed in the United States for over fifty years, yet the equal pay gap continues to be an issue for working women across all professions. ${ }^{1}$ Professional female athletes fight a much larger pay disparity than working women in conventional careers because the higher a woman's salary, the greater the wage gap. ${ }^{2}$ Despite the vast pay disparity between professional male and female athletes, female athletes are not suing to gain pay equality in the United States. In fact, the Women's National Soccer Team's complaint-filed with the Equal Employment Opportunity Commission detailing the unequal pay they received from their governing body, the United States Soccer Federation - was the first legal action taken by professional athletes of its kind. ${ }^{3}$ This raises the question, with such a large gender pay gap in professional sports, why aren't more female athletes suing their governing bodies in order to obtain equal pay?

This Note will explore the issue of gender pay inequality in professional sports and whether Iceland's new legislation, enacted in January 2018, would help achieve pay equality for female athletes. ${ }^{4}$ In Part 1 , this Note will provide background and historical information about the gender pay gap nationally in the United States as well as in professional sports. This Note will examine the popular cases of the Women's National Soccer Team and the Women's National Hockey Team, as well as pay equality issues in other professional sports. Part 2 will detail the current legislation used in the U.S. in pay inequality cases, including the Equal Pay Act and Title VII of the Civil Rights Act. Part 3 of this Note will detail Iceland's history of leading the world in gender equality issues and the new legislation this country enacted with the specific purpose of eliminating gender pay inequality in all careers. Finally, part 4 will determine whether the United States should enact legislation similar to Iceland's new law in order to fight pay inequality more effectively in professional sports.

* Doctor of Jurisprudence Candidate, 2019, Indiana University Robert H. McKinney School of Law; Bachelor of Arts in Communication, Magna Cum Laude, 2013, DePauw University. The author would like to thank the faculty and staff of Indiana University Robert H. McKinney School of Law for challenging and supporting her work. Particularly her faculty advisor, Professor Allison Martin and the board of the Indiana International \& Comparative Law Review.

1. The Simple Truth about the Gender Pay Gap, AAUw (2016), https://www.aauw.org/ research/the-simple-truth-about-the-gender-pay-gap/ [https://perma.cc/M3XJ-NFY2].

2. Deborah Thompson Eisenberg, Shattering the Equal Pay Act's Glass Ceiling, 63 S.M.U.L. REV. 17 (2010).

3. Laura Santhanam, Data: How Does the U.S. Women's Soccer Team Pay Compare to the Men?, PBS (Mar. 31, 2016), https://www.pbs.org/newshour/nation/data-how-does-the-u-s-womenssoccer-team-pay-compare-to-the-men [https://perma.cc/7PDA-L2RU].

4. Act on Equal Status and Equal Rights of Women and Men, 2008 (Act No. 10/2008) (Ice.). 


\section{BACKGROUND ABOUT THE GENDER PAY GAP}

\section{A. The Gender Pay Gap Nationally}

The gender pay gap is an issue for working women across all fields and careers. Women are consistently paid less than their male counterparts in the same or similar positions. ${ }^{5}$ The gender pay gap is defined as "the difference between men's and women's average gross earnings, divided by the average of men's gross earnings." This calculation shows the reduced pay women receive for doing the same work. In the United States, women are paid about $80 \%$ of what men are paid. ${ }^{7}$ Despite having passed equal pay legislation over fifty years ago, the U.S. still has a large gender pay gap, ranking $45^{\text {th }}$ in the world. ${ }^{8}$ If the U.S.'s gender pay gap continues to change at the same rate it has since equal pay legislation was passed in the 1960s, women will not be paid equally compared to their male counterparts until 2059. ${ }^{9}$ Other experts predict that it will take much longer to achieve pay equality, potentially not until 2119 , because change has stalled..$^{10}$

The pay gap is even more disturbing as women move up the ladder in their careers. ${ }^{11}$ "This barrier [the equal pay gap] is particularly troubling in light of data that shows that the gender wage gap increases for women as they achieve higher levels of professional status." ${ }^{\prime 2}$ Female athletes are affected by the gender pay gap more than average working women because many of their salaries rise far above the average pay for women in conventional careers. Professional athletes have a higher level of professional status. Therefore, the gender pay gap for athletes is even greater. The current laws in the United States, including the Equal Pay Act and Title VII of the Civil Rights Act, are no longer impacting pay equality or improving the pay disparity. Further legislation is needed to improve pay equality for women in all careers, and specifically for women in professional sports.

5. The Simple Truth about the Gender Pay Gap, supra note 1.

6. Jarrod Tudor, Closing the Gender Pay Gap in the European Union: The Equal Pay Guarantee Across the Member States, 92 N.D. L. REV. 415, 418 (2017).

7. Eisenberg, supra note 2, at 24; see also Shawn M. Carter, In the US, Unlike in Iceland, It's Still OK to Pay a Woman Less Than a Man - Here's Why, CNBC, (Jan. 9, 2018), https://www.cnbc.com/2018/01/09/in-the-us-unlike-iceland-its-still-ok-to-pay-women-less-hereswhy.html [https://perma.cc/P7MT-BZN8].

8. Global Gender Gap Report 2016, WORLD ECONOMIC FORUM, http://reports.weforum. org/global-gender-gap-report-2016/economies/\#economy=USA (follow Country Profiles: United States and Country Profiles: Iceland) (last visited Dec. 1, 2019) [https://perma.cc/B794-QFDZ].

9. The Simple Truth about the Gender Pay Gap, supra note 1.

10. Carter, supra note 7.

11. Eisenberg, supra note 2.

12. Id. at 17 . 


\section{B. The Gender Pay Gap in Professional Sports}

The gender pay gap in sports is much wider than the $80 \%$ pay gap that represents the United States as a whole. ${ }^{13}$ In 2018, Forbes ranked the top 100 highest paid professional athletes in the world, and not a single one was a woman. ${ }^{14}$ This represents the first time in eight years that no female athletes made this list. ${ }^{15}$ Even in past years there has not been more than a handful of female athletes represented. ${ }^{16}$ Often times only one female athlete, Serena Williams, made the list. ${ }^{17}$ Forbes' list of highest paid professional athletes includes mostly National Basketball Association, National Football League, and Major League Baseball players. ${ }^{18}$ Even after combining the top ten highest paid female athletes' income, three male athletes still earned more than all of these women collectively. ${ }^{19}$ These facts demonstrate the sizable wage gap among female athletes in professional sports and the stall in progress in recent years.

Professional athletes are paid on a much different scale than the average working men and women in the U.S. Athletes' pay differs drastically based on the sport and the league. Athletes sign a contract with a particular team that consists of a base salary and often a signing bonus. ${ }^{20}$ The base salary is usually guaranteed money even if the athlete is injured or released from the team. ${ }^{21}$ These contracts can be for a year or several years. ${ }^{22}$ For many sports, athletes and teams or team owners agree to collective bargaining agreements that set a minimum salary for lesser known, less established athletes. ${ }^{23}$ Additionally, organizations like the National Football League have salary caps for individual

13. A Look at Male and Female Professional Athlete Salaries, ADELPHI UnIVERSiTy (Aug. 11, 2014), https://sportsmanagement.adelphi.edu/resources/infographics/a-look-at-male-andfemale-professional-athlete-salaries/ [https://perma.cc/J2PR-DUL5]; see also The Simple Truth about the Gender Pay Gap, supra note 1.

14. Kim Elsesser, 8 Unbelievable Gender Pay Gap Statistics from Top Athletes, Actors, and CEOs, FOrBes (Aug. 27, 2018), https:/www.forbes.com/sites/kimelsesser/2018/08/27/8unbelievable-gender-pay-gap-statistics-from-top-athletes-actors-and-ceos/\#743817416559 [https://perma.cc/5L29-62MZ].

15. Jessica Spitz, The Top 100 Highest Paid Athletes in the World Made \$3.8 Billion. No Women Made the List., NBC NEws (June 7, 2018), https://www.nbcnews.com/news/sports/top-100highest-paid-athletes-world-made-3-8-billion-n881151 [https://perma.cc/9ENM-P9GB].

16. Id.

17. Id.

18. Id.

19. Elsesser, supra note 14.

20. How Much Do Professional Athletes Make?, Quintessentially People (June 21, 2017), http://www.quintessentiallypeople.com/blog/how-much-do-athletes-make [https://perma.cc/78HWCXVG].

21. Id.

22. Id.

23. $I d$. 
teams that require the team as a whole to only spend a set amount of money on all their athletes' salaries combined for that year. ${ }^{24}$ Athletes usually have the opportunity to earn more money based on the team's success. ${ }^{25}$ If the team qualifies for tournaments or championships, the athlete will typically receive a performance bonus. ${ }^{26}$

Another large aspect of an athlete's income is endorsement deals. Because of athletes' star power and influence, big brands are willing to pay millions of dollars to get these professional sports men and women to advertise their products. ${ }^{27}$ Typically, these deals are available to more popular athletes, often the ones that are already making a significant amount of money from their clubs and organizations. ${ }^{28}$ Endorsement deals can add millions to an athlete's income annually. ${ }^{29}$

Some professional sports, such as tennis, pay players based on tournament play and wins. ${ }^{30}$ This means that athletes will earn money for participating and winning tournaments, instead of having a base salary. ${ }^{31}$ Other sports, such as hockey and soccer, compete as both national teams and Olympic teams.

One main difference between athletes' careers and working citizens in nonathletic careers is their longevity. Most professional athletes start and finish their careers in their twenties. ${ }^{32}$ Consequently, the large salaries they make only last for a few years. However, athletes' salaries increase at a rate much quicker than the workforce as a whole, allowing them to maximize their earnings during their short careers. ${ }^{33}$

The United States' Women's National Soccer Team voiced their concerns about the gender pay gap in professional sports, using their star power to bring light to the pay gap injustice.

The United States' Women's National Soccer Team ("WNT" or "Women's National Team") were the first female athletes to take a legal stand against the gender wage gap. ${ }^{34}$ In 2016, the Women's National Team filed a discrimination claim with the Equal Employment Opportunity Commission (EEOC) asserting that they received unequal pay compared to their male counterparts, despite being far more successful than the male team. ${ }^{35}$ Players Hope Solo, Carli Lloyd, Megan

24. John Perritano, How Does the NFL Salary Cap Work?, HowStuffWorks (May 25, 2001), https://entertainment.howstuffworks.com/question644.htm [https://perma.cc/7YQN-F7PM].

25. How Much Do Professional Athletes Make?, supra note 20.

26. Id.

27. $I d$.

28. Id.

29. Id.

30. Id.

31. $I d$.

32. Id.

33. Id.

34. Santhanam, supra note 3.

35. EEOC Charge, HufFINGTON POST (Mar. 29, 2016), http://big.assets.huffingtonpost.com/ EEOCCharge.pdf [https://perma.cc/AK4H-BMKP]. 
Rapinoe, Rebecca Sauerbrunn, and Alex Morgan stated:

The [Women's National Team] has enjoyed unparalleled success in international soccer, winning three World Cup titles and four Olympic Gold Medals - an accomplishment that no other country on the men's or women's side has reached in Olympic competition ... Unfortunately, the WNT's on-field accomplishments and revenue generation have not resulted in us or our fellow players earning equal or better pay than MNT [Men's National Team] players. ${ }^{36}$

Despite their undeniable success, the Women's National Team players receive far less pay compared to the male players. ${ }^{37}$ The WNT players list many examples of the discriminatory pay they receive from the United States Soccer Federation (USSF), the sport's governing body. In 2015, the Women's National Team earned \$2 million for winning the World Cup, a world-wide soccer tournament. ${ }^{38}$ That same year, the Men's National Team received $\$ 9$ million for losing in the sixteenth round. ${ }^{39}$ Meanwhile, Germany's winning men's team at the 2014 World Cup received \$35 million. ${ }^{40}$ The Women's National Team received \$7 million less than the Men's National Team and \$33 million less than Germany's winning men's team in the same tournament. ${ }^{41}$

Additionally, the players demonstrated that they were paid between $38 \%$ and $72 \%$ of what the male players were paid per game for regular season games called friendlies. ${ }^{42}$ If the WNT wins all twenty of these friendlies and the men's team loses all of these games, the men would still be paid $\$ 1,000$ more than the women. ${ }^{43}$ The maximum base pay the WNT players could earn from winning all the friendlies is $\$ 99,000$, while the maximum the men could earn from winning all of these games is $\$ 260,000 .^{44}$ Evidently, winning games and world tournaments is not driving the compensation of the Women's National Team or the Men's National Team, because the women are not outearning the men despite their superior play on the field.

This EEOC claim filed by the Women's National Team players even caught

36. Id.

37. Id.

38. Id. See also Zachary Zagger, Soccer EEOC Charge Seen as Milestone for Women Athletes, LeXIS, (Mar. 31, 2016).

39. EEOC Charge, supra note 35.

40. Kelsey Clark, Gender Pay Gap for Women Athletes, IneQuAlity (July 30, 2015), https://inequality.org/great-divide/gender-pay-gap-athletes/ [https://perma.cc/EYH3-ZHZG]; see also Pay Inequity in Athletics, Women's SpORTs Foundation (July 20, 2015), https://www. womenssportsfoundation.org/research/article-and-report/elite-athletes/pay-inequity/ [https://perma.cc/7HXN-BSGN].

41. EEOC Charge, supra note 35; see also Zagger, supra note 38.

42. EEOC Charge, supra note 35.

43. Zagger, supra note 38.

44. Senate Urges Equal Pay for US Women's Soccer Team, LeXIS (May 27, 2016). 
the attention of the United States Senate who "passed a nonbinding resolution that calls upon US Soccer to 'immediately end gender pay inequity and to treat all athletes with the respect and dignity those athletes deserve." ${ }^{45}$

Despite the countless examples the women's team offered as evidence of the pay discrimination, the United States Soccer Federation argued that the pay disparity is an economic issue rather than discrimination. ${ }^{46}$ Anticipating this response, the players leading the EEOC claim laid out many reasons why this excuse is simply not true.

The Women's National Team's 2015 World Cup win was watched by over 23 million viewers. ${ }^{47}$ This makes the 2015 World Cup final match the most watched soccer game in U.S. history and the largest viewership for an Englishspeaking broadcast of any soccer game. ${ }^{48}$ The players stated that they participated in a victory tour that generated tens of millions of dollars for the USSF. $^{49}$ The Women's National Team generated nearly \$20 million more for the United States Soccer Federation than the Men's National Team. ${ }^{50}$

Additionally, the players argued that their success leads them to play more games than the male team, which results in more media interviews, more travel, and more training. ${ }^{51}$ None of these facts result in more compensation for these female athletes. The Women's National Team is more successful than the male team, creates more viewership in the United States than the male team, and generates more money for the USSF than the male team, yet they do not receive equal or more compensation compared to the men's national team players. ${ }^{52}$

In April 2017, the Women's National Team was able to reach an agreement with the United States Soccer Federation for a new labor deal. ${ }^{53}$ The agreement increased pay for players at all levels, offered better travel and hotel accommodations, and reimbursed players for years when their per game allowance was less than the men's national team players. ${ }^{54}$ This new agreement will take the team through the next World Cup and the 2020 Olympics. ${ }^{55}$ The

45. Louisa Thomas, Equal Pay for Equal Play: The Case for the Women's Soccer Team, THE NEw YORKER (May 26, 2016) https://www.newyorker.com/culture/cultural-comment/the-case-forequal-pay-in-womens-sports [https://perma.cc/C78L-2CUL] (quoting S. Res. 462, 114th Cong., 162 CONG. ReC. 2751 (2016) (enacted)).

46. Bryan Baxter, US Women's Soccer Team Ousts Dallas Leader, TeX. L., LeXIS (Dec. 30, 2016).

47. EEOC Charge, supra note 35.

48. Id. See also Thomas, supra note 45.

49. EEOC Charge, supra note 35.

50. See also Thomas, supra note 45.

51. EEOC Charge, supra note 35.

52. Id. See also Thomas, supra note 45.

53. Ahiza Garcia, U.S. Women's Soccer Team Gets a Raise in New Labor Deal, CNN MonEY (Apr. 5, 2017), https://money.cnn.com/2017/04/05/news/us-womens-soccer-equal-pay/index.html [https://perma.cc/UR8R-F8ML].

54. Id.

55. Id. 
specific details of this agreement have remained private, including the amount of the pay increase and whether the team will receive equal prize money for World Cup wins. Coincidently, this agreement was made just days after the national Equal Pay Day which is meant to acknowledge the gender pay gap. ${ }^{56}$

Unfortunately, the Women's National Soccer Team is not the only female professional sports team to experience gender wage discrimination. The Women's National Hockey Team also expressed a similar concern for pay disparity between the women's team players and the male players. ${ }^{57}$

In 2017, the Women's National Hockey Team announced their plans to boycott the United States hosted championship unless they received equal pay and more support. ${ }^{58}$ In hockey, the pay disparity is even greater. Many female hockey players hold multiple jobs on top of being professional hockey players to make ends meet. ${ }^{59}$ This is all despite the fact that the Women's National Hockey Team won back-to-back silver medals. ${ }^{60}$ In fact, the team has medaled in every Olympics since hockey was added as an Olympic sport. ${ }^{61}$

The female hockey players were only asking for a base salary of $\$ 68,000$ and to be treated similarly to their male counterparts. ${ }^{62}$ The women wanted the ability to bring guests to games and disability insurance, all things offered to the male hockey players. ${ }^{63}$ The women's team players not only fought for equal pay for themselves but also wanted the national governing body to invest in better programs for girls' hockey across the nation. ${ }^{64}$ In this situation, female athletes were fighting to be paid enough so they would not have to work multiple jobs. These are athletes that represent the United States in the Olympics and world tournaments, and yet they cannot make ends meet with their salaries.

Ultimately, the Women's National Hockey Team reached a deal with USA Hockey. ${ }^{65}$ The details of the deal have not been disclosed but players reported being satisfied with the outcome. ${ }^{66}$

The secrecy behind these deals with women's national hockey and soccer teams and their governing bodies does not help all female athletes gain pay equality. If these deals truly represent equal pay, they could be used as examples

56. Id.

57. Sean Gregory, How Female Athletes Can Help Advance the Fight for Fair Pay, Time (Mar. 23, 2017), http://time.com/4710628/female-athletes-fair-pay/ [https://perma.cc/SB4U-99YJ].

58. $I d$.

59. Id.

60. Id.

61. Ahiza Garcia, US Women's Hockey: From Fighting for Better Pay to Fighting for Gold, CNN (Feb. 21, 2018), https://money.cnn.com/2018/02/21/news/us-womens-hockey-olympics/ index.html [https://perma.cc/6BDQ-F8PP].

62. Id.

63. $I d$.

64. Gregory, supra note 57.

65. Garcia, US Women's Hockey, supra note 61.

66. Id. 
for other sports organizations to make changes and support their athletes. The fact that they are kept secret and the female players are told not to discuss the details of these contracts leads to uncertainty as to whether these deals actually represent fair and equal pay and it keeps the public and the media out of this important controversy.

The gender pay gap continues to affect all female professional athletes in almost all sports. In basketball, the maximum salary for Women's National Basketball Association (WNBA) players is $\$ 111,500 .{ }^{67}$ Meanwhile, the minimum salary for a National Basketball Association (NBA) male player is $\$ 525,093 .^{68}$ If this statistic is not enough to express the gross pay disparity among professional male and female basketball players just look at their average salaries. The average salary in the NBA is $\$ 4.5$ million and the average salary in the WNBA is $\$ 72,000 .^{69}$ Millions of dollars in pay separate basketball players just because of their gender.

In tennis, Venus Williams fought for equal prize money to be awarded to the winners of the biggest tournaments. ${ }^{70}$ After nine years of drawing attention to the pay gap in prize money for the winners of the men's matches compared to the winners of the women's matches, the last big tournament, Wimbledon, finally provided equal prize money to both winners. ${ }^{71}$ This represented a huge win for female tennis players. Venus Williams used her voice and celebrity to make others aware of this issue. She did not use the courtroom.

In golf, the average salary for a golfer in the Professional Golfers' Association (PGA) is $\$ 973,000$, meanwhile the average salary for a female golfer in the Ladies Professional Golf Association (LPGA) is $\$ 162,000 .^{72}$ Women in professional golf make just $16.6 \%$ of what male professional golfers make annually. ${ }^{73}$

The gender pay gap in professional sports impacts all female athletes. The pay disparity that separates female athletes from male athletes can be as much as millions of dollars a year. It makes sense that no women made the 2018 Forbes' list of one hundred highest-paid athletes because male athletes more commonly receive endorsement deals and other opportunities that female athletes are not offered on top of receiving a much larger base salary from their governing organizations and clubs. ${ }^{74}$ Despite the endless gender pay discrepancies in sports, many female athletes are not taking their claims to the courtroom. Instead, they

67. Temika Hampton, Why Should We Care About the Gender Pay Gap in Professional Sports?, AMERICAN BAR (Aug. 9, 2017), https://www.americanbar.org/groups/young_lawyers/ publications/tyl/topics/sports-and-entertainment-law/why-should-we-care-about-the-gender-paygap-in-professional-sports/ [https://perma.cc/S7F3-BFKF].

68. Id.

69. A Look at Male and Female Professional Athlete Salaries, supra note 13.

70. Hampton, supra note 67.

71. Id.

72. A Look at Male and Female Professional Athlete Salaries, supra note 13.

73. $I d$.

74. Spitz, supra note 15. 
are using their celebrity status to shame their sports organizations, like Venus Williams, or threatening to boycott competitions, like the Women's National Hockey Team. In an effort to make sense of why professional female athletes are not suing, the next section will examine the current equal pay legislation in the United States and the faults within this legislation that limit women's ability to seek justice for discriminatory pay.

\section{THE INADEQUACY OF THE UNITED STATES' CURRENT EQUAL PAY LAWS}

The Equal Pay Act of 1963 and Title VII of the Civil Rights Act are the two main laws used to bring equal pay issues into the courtroom. Despite providing two paths to receive a judgment, these laws have many barriers that women cannot overcome when proving their pay discrimination cases. This section will focus on these two laws individually and examine why these laws are not successful in closing the gender wage gap in the United States. First, this section will examine the Equal Pay Act of 1963 and how an employment discrimination case can be brought to court under this law. The discussion will then expand to demonstrate why the Equal Pay Act is not successful, including an analysis of the defenses employers can assert to protect themselves in these cases. Next, Title VII of the Civil Rights Act will be explored, including a detailed description of how employees can file a claim under this law. Following this discussion, an analysis of the difficulty employees have proving intentional discrimination will demonstrate why this law is not successful in closing the gender pay gap.

\section{A. The Equal Pay Act}

The Equal Pay Act (EPA) was established to enforce that men and women be given equal compensation for doing the same work. ${ }^{75}$ The focus of equal work is supposed to be on job content, not job titles. ${ }^{76}$ The need for equal pay legislation became evident during World War II when women took over jobs for men who enlisted in the military. ${ }^{77}$ However, efforts to pass equal pay legislation during World War II failed. ${ }^{78}$ By 1960, women earned about one-third of what their male counterparts earned. ${ }^{79}$ During the Kennedy administration, female leaders such as Esther Peterson and Eleanor Roosevelt fought hard for this

75. Facts about Equal Pay and Compensation Discrimination, EEOC, https://www.eeoc.gov/ eeoc/publications/fs-epa.cfm (last visited Feb. 16, 2019) [https://perma.cc/2S4X-Y8U8] and Andrea Boyle Tippett, Star Power Squandered: Study Finds Female Athletes Rarely and Ineffectively Used as Ad Spokespeople, Univ. OF Delaware Daily (July 30, 2012), http://www1.udel.edu/udaily/ 2013/jul/study-female-athletes-073012.html [https://perma.cc/B9QG-K68Q].

76. Id.

77. Equal Pay Act, History (Aug. 21, 2018), https://www.history.com/topics/womensrights/equal-pay-act [https://perma.cc/TE8F-KU66].

78. Id.

79. Id. 
amendment to the Fair Labor Standards Act of $1938 .{ }^{80}$ The Equal Pay Act was the first federal law that addressed gender wage discrimination. ${ }^{81}$ At the time this law was passed, even President Kennedy recognized a need for more protection at the signing of the bill when he stated "much remains to be done to achieve full equality of economic opportunity [for women]." remarks, little has changed since the passage of this law to improve economic opportunity for women.

Under the EPA, a plaintiff must establish a prima facie violation that demonstrates the plaintiff was paid less than an employee of the opposite sex for equal work and responsibilities. ${ }^{83}$ The statute's purpose is "to prohibit discrimination on account of sex in the payment of wages by employers engaged in commerce or in the production of goods for commerce." ${ }^{.94}$ The plaintiff does not have to prove discriminatory intent to succeed on an EPA claim. ${ }^{85} \mathrm{~A}$ violation of the EPA is also a violation of Title VII of the Civil Rights Act. ${ }^{86}$ If a plaintiff successfully argues her case for equal pay, she can recover wages owed and attorney's fees. ${ }^{87}$ Compensatory and punitive damages are available under the EPA. ${ }^{88}$ There is no prerequisite of exhausting administrative remedies or filing with a certain agency. ${ }^{89}$ The issue with the Equal Pay Act is not in regards to how the plaintiff files or proves a discriminatory pay claim but in the four defenses employers can assert to justify this discriminatory pay that are accepted as legitimate reasons for paying women less.

There are four defenses the employer can assert as excusable reasons why the employee is paid less than a member of the opposite sex. ${ }^{90}$ These defenses include: the pay scale is based on a (i) seniority system; (ii) merit system; (iii) a system that measures quality or quantity of production; or the pay is based on (iv) any factor other than sex. ${ }^{91}$ The employer can also argue that the jobs are not

80. Id.

81. Id.

82. Id.

83. Relationship to the Equal Pay Act of Title VII of the Civil Rights Act, 29 C.F.R. $\S$ 1620.27 (2018).

84. Equal Pay Act of 1963, Pub. L. No. 88-38, 77 Stat. 56 (1963) (current version at 29 U.S.C. § 206(d) (2019)).

85. Strecker v. Grand Forks Cty. Soc. Serv. Bd., 640 F.2d 96, 100 n.1 (8th Cir. 1980).

86. 29 C.F.R. $\S 1620.27$.

87. 29 U.S.C. $\$ 216$ (b) (2019).

88. Travis v. Gary Cmty. Mental Health Ctr., Inc., 921 F.2d 108, 112 (7th Cir. 1990) (holding that punitive damages are available under the Fair Standards Labor Act for intentional torts including retaliatory acts).

89. Diane Heckman, The Entrenchment of the Glass Sneaker Ceiling: Excavating Forty-Five Years of Sex Discrimination Involving Educational Athletic Employment Based on Title VII, Title $I X$, and the Equal Pay Act, 18 VILl. SporTs \& ENT. L. J. 429, 446 (2011); see also Eisenberg, supra note 2 , at 35 .

90. 29 U.S.C. $§ 206(d)(2006)$.

91. Id. 
equal and that is why the compensation is not equal. ${ }^{92}$ These defenses allow employers a way out of equal pay lawsuits because the employers can argue literally anything other than sex to justify the pay.

After reexamining some of the arguments the United States Soccer Federation made in response to the Women's National Team's Equal Employment Opportunity Commission complaint, the vast protection these defenses offer becomes clear. Should the Women's National Team decide to pursue their complaint in court, their employer has many defenses they can assert to justify why the female athletes are compensated less than the male athletes.

The United States Soccer Federation argued in their response to the Women's National Team's complaint that the men's pay scale was based on a high risk, high reward model where a male player that was not called to camp or became injured would receive no compensation. ${ }^{93}$ Meanwhile, the USSF contended, the women chose to pick a more conservative pay scale with guaranteed money. ${ }^{94}$ This excuse can fall under either the merit system defense or the quantity/quality system defense because, essentially, the USSF was saying that the men can make more or less depending on their success and the risk they are taking is whether they will win or lose games. Nevertheless, the female athletes do not get paid more even when they win more games.

Remember when the Women's National Team won the World Cup they received \$2 million, meanwhile, the men who lost in the sixteenth round received $\$ 9$ million. ${ }^{95}$ Moreover, the Women's National Team's players would receive $\$ 1,000$ less than the Men's National Team's players even if the women won all of their regular season games and the men lost all of their competitions. ${ }^{96}$ The merit system defense does not justify why the women make far less than the men even when they are more successful. Yet, this defense is available to the USSF.

The USSF can assert a quantity system defense to justify the unequal pay the Women's National Team receives. However, because the Women's National Team is more successful and progresses further in tournaments, they end up playing more matches than the Men's National Team. ${ }^{97}$ Despite this, the female athletes do not get paid more even when they play more games. The quantity/quality system defense still does not explain why the men, who play

92. Corning Glass Works v. Brennan, 417 U.S. 188, 209-10 (1974) (holding that day shift inspectors, which consisted mostly of women, and night shift inspectors, which were predominantly male, performed equal work regardless of the time of day the work was being performed and the employer was discriminating against female inspectors by paying them substantially less than male inspectors).

93. Andrew Das, Pay Disparity in U.S. Soccer? It's Complicated., N.Y. TIMES (Apr. 21, 2016), https://www.nytimes.com/2016/04/22/sports/soccer/usmnt-uswnt-soccer-equal-pay.html [https://perma.cc/P6VJ-668R].

94. $I d$.

95. EEOC Charge, supra note 35.

96. Zagger, supra note 38.

97. EEOC Charge, supra note 35. 
fewer games, get paid more than the women. Under the Equal Pay Act, both of these defenses could be argued by the USSF.

The final defense the USSF could assert is the any factor other than sex defense. This defense is the most common defense used by employers in athletic employment discrimination cases. ${ }^{98}$ Because this defense is regularly used in these cases and is often successful, it is proof that the EPA is not working to end discrimination in athletics. Raising revenue is often the claim made by employers under this defense. ${ }^{99}$ Employers claim that female athletes and female sports in general do not raise as much revenue for their organizations as male sports, thus supposedly justifying why female athletes and coaches are paid less. ${ }^{100}$ Unfortunately courts are very accepting of this defense. ${ }^{101}$ For example, in Stanley v. University of $S$. Cal., the Court held that raising revenue made the men's basketball coach's job substantially different from the women's basketball coach's job. ${ }^{102}$ Thus, the court ruled the women's basketball coach (plaintiff) did not have sufficient facts to support a finding of gender discrimination. ${ }^{103}$

In the case of the Women's National Team, the players addressed these concerns in their complaint filed with the EEOC. ${ }^{104}$ The Women's National Team generated more revenue than their male counterparts and more television viewership. ${ }^{105}$ The players stated that they generated \$20 million more for the USSF than the men's team. ${ }^{106}$ The World Cup win by the Women's National Team was the most watched soccer match in United States history. ${ }^{107}$ These facts should help the team fight this defense should this issue ever be litigated but because of the success employers have using this defense, it is unclear whether the female athletes in this case would be able to win the lawsuit.

Lack of viewership and fans is often stated as the reason female athletes get paid less than male athletes. The Equal Pay Act does not take into consideration that sex discrimination is the cause of the lack of marketing and television opportunities for female sports and athletes. For example, in European sports news shows over $88 \%$ of news stories are about male athletes. ${ }^{108}$ In the United States, a study done by the Tucker Center for Research on Girls and Women in

98. Heckman, supra note 89 , at 446.

99. Id.

100. Id.

101. Id.

102. Stanley v. University of S. Cal., 13 F.3d 1313, 1323 (9th Cir. 1994).

103. Id. See also Jacobs v. Coll. of William \& Mary, 517 F. Supp. 791, 798 (E.D. Va. 1980) (stating that the fact that the men's basketball team is revenue producing and the women's basketball team is not is important when comparing job responsibilities).

104. EEOC Charge, supra note 35.

105. Id.

106. Thomas, supra note 45.

107. EEOC Charge, supra note 35.

108. European Comm'n, Sports, Media and Stereotypes Women and Men in Sports and Media, CENTRE FOR GENDER EQUALITY IN ICELAND at 9, http://www.mujerydeporte.org/documentos/docs/ sms_summary_report.pdf(last visited Dec. 1, 2019) [https://perma.cc/PRR9-ZQPP]. 
Sports found that only $4 \%$ of sports media coverage is about women's sports or female athletes. ${ }^{109}$ Media coverage helps generate viewers and fans which leads to sponsorships, endorsements, and revenue in ticket sales. Because professional female athletes receive painstakingly low coverage in the media, they are already at a disadvantage when it comes to earning revenue and generating fans for their governing organizations and sports.

The Equal Pay Act does not take into account that women are not given an equal opportunity to make profits for their organizations. This is a central reason why the EPA does not decrease gender discrimination in athletics. The law fails to recognize the vast discrimination in all facets of the sports industry that leads to decreased revenue generation for female sports. Revisiting Stanley v. University of S. Cal, the court stated that USC's decision not to promote women's basketball games was not gender discrimination but a business decision "to allocate USC resources to the team that generates the most revenue." 110 The women's basketball team at USC was not given an equal opportunity to earn revenue through ticket sales because their games were not promoted the same way the men's team competitions were promoted. The gender discrimination in sports already assumes women's teams are going to earn less money and courts have allowed for schools to unequally allocate resources to promote men's sports thus continuing the cycle of discrimination.

The Ninth Circuit took a progressive stand against employers using the "any factor other than sex" defense in the case Rizo v. Yovino. ${ }^{111}$ The Court held that prior salary, whether alone or in combination with other factors, will not justify wage discrepancies. ${ }^{12}$ In other words, employers cannot use an employee's prior salary as a way to justify less pay than employees of the opposite sex. In his opinion, Judge Reinhardt states, "To hold otherwise - to allow employers to capitalize on the persistence of the wage gap and perpetuate that gap ad infinitum - would be contrary to the text and history of the Equal Pay Act, and would vitiate the very purpose for which the Act stands." 113 Unfortunately, the Supreme Court of the United States ruled that because Judge Reinhardt passed away before his en banc decision in this case was officially filed, his vote and opinion could not be counted. ${ }^{114}$

Finally, a successful lawsuit under the Equal Pay Act requires there to be another employee with an equal job for the plaintiff to compare their own salary against. ${ }^{115}$ While it is unknown whether professional athletes will have a difficult time meeting this requirement, the fact that most women suing under the EPA

109. Lilit, Gender Discrimination in Sports: Statistics and Examples, WoMEN's Forum (Feb. 26, 2018), https://women-s.net/gender-discrimination-in-sports/ [https://perma.cc/DJ3F-MJ2E].

110. Stanley v. University of S. Cal., 13 F.3d 1313, 1323 (9th Cir. 1994).

111. Rizo v. Yovino, 887 F.3d 453, 456 (9th Cir. 2017).

112. Id.

113. Id. at 456-57.

114. Yovino v. Rizo, 139 S. Ct. 706, 710 (2019).

115. Miranda v. B \& B Cash Grocery Store, Inc., 975 F.2d 1518, 1533 (11th Cir. 1992). 
face this issue could mean it would be a barrier for female athletes. Cases involving the EPA have revealed:

Courts have, over time, interpreted the requirement that the jobs be equal so restrictively that plaintiffs today rarely satisfy the prima facie standard ... the EPA is increasingly becoming an empty promise, unworkable and ineffective to remedy wage discrimination for many women . . . the EPA's prima facie standard - which requires that the jobs be equal in terms of skill, effort and responsibility - is not a workable standard for women in non-standardized ... jobs. ${ }^{116}$

Because professional athletes sometimes work for different clubs or play in different leagues, courts could be hesitant to let women compare their jobs to male athletes in these different organizations. Courts have also allowed the argument that responsibilities are not the same for sports that make more revenue than others, because the stakes are supposedly higher, to be used in this defense. ${ }^{117}$ Additionally, there is always the age-old biological argument that could be used against women that male sports are allegedly "more physical" thus not making male athletes an equal comparison for female athletes.

The Equal Pay Act has been in effect for forty-six years, yet there have only been 197 published appellate cases. ${ }^{118}$ The success rate of a plaintiff's claim on appeal is only $35 \% .{ }^{119}$ The court of appeals affirmed summary judgment motions in favor of the employer $92 \%$ of the time from 2000 to $2009 .{ }^{120}$ For appellate plaintiffs represented by a government agency (for example, the EEOC) the success rate of cases is $73 \%$, but for private plaintiffs the success rate is only 44\%. ${ }^{121}$ Judge Reinhardt made the following statement regarding the success of the Equal Pay Act, "Although the Act has prohibited sex-based wage discrimination for more than fifty years, the financial exploitation of working women embodied by the gender pay gap continues to be an embarrassing reality of our economy."

Perhaps the most telling example that the Equal Pay Act is not adequate to combat pay discrimination in professional sports is that female athletes are not suing to fix this problem. ${ }^{123}$ Instead, many female athletes determined that using

116. Eisenberg, supra note 2, at 22-23 ("A plaintiff establishes a prima facie case by comparing the jobs held by the female and male employees, and by showing that those jobs are substantially equal, not by comparing the skills and qualifications of the individual employees holding those jobs.").

117. Stanley v. University of S. Cal., 13 F.3d 1313, 1323 (9th Cir. 1994) ("The responsibility to produce a large amount of revenue is evidence of a substantial difference in responsibility."); see also Jacobs v. Coll. of William \& Mary, 517 F. Supp. 791, 798 (E.D. Va. 1980).

118. Eisenberg, supra note 2, at 32.

119. Id. at 33 .

120. Id. at 34 .

121. Id. at 36 .

122. Rizo v. Yovino, 887 F.3d 453, at 456.

123. Santhanam, supra note 3. 
their celebrity and voices through social media and television is a more cost effective way to raise concerns about gender pay discrimination and produces more results from their prejudiced employers.

\section{B. Title VII of the Civil Rights Act}

Title VII of the Civil Rights Act is another law used in gender pay discrimination cases. Title VII states:

It shall be an unlawful employment practice for an employer (1) to fail or refuse to hire or to discharge any individual, or otherwise to discriminate against any individual with respect to his compensation, terms, conditions, or privileges of employment, because of such individual's race, color, religion, sex, or national origin. ${ }^{24}$

Title VII was enacted in $1964 .{ }^{125}$ The process of enacting the Civil Rights Act, which includes Title VII, involved the longest debate in Congress's 180 year history. ${ }^{126}$ Congress debated the bill for 534 hours. ${ }^{127}$ Title VII applies to private employers, labor unions, and employment agencies of fifteen employees or more. ${ }^{128}$ Title VII created the Equal Employment Opportunity Commission (EEOC). ${ }^{129}$ The EEOC is a five member bipartisan commission appointed by the president whose mission is to eliminate unlawful discrimination in the work force. ${ }^{130}$

Under Title VII, the employee must first file administrative complaints with the EEOC. ${ }^{131}$ To succeed on a Title VII claim, the plaintiff must demonstrate (1) the individual is a member of a protected class, (2) the individual was qualified for the job, (3) the individual suffered an adverse employment action taken by the defendant, and (4) circumstances existed to support an inference of discrimination by the defendant. ${ }^{132}$ The damages available under a Title VII claim include injunctive relief, compensatory damages, back pay, front pay, and potential damages. ${ }^{133}$ Title VII is different from the Equal Pay Act because it applies not

124. 42 U.S.C. $\S 2000 \mathrm{e}-2(\mathrm{a})(1)$ (2019).

125. U.S. Equal Employment Opportunity Commission $35^{\text {th }}$ Anniversary, EEOC https://www. eeoc.gov/eeoc/history/35th/milestones/1964.html (last visited Dec. 1, 2019) [https://perma.cc/Y3RC-9BEY].

126. Id.

127. Id.

128. U.S. Equal Employment Opportunity Commission $35^{\text {th }}$ Anniversary, EEOC, https://www. eeoc.gov/eeoc/history/35th/thelaw/index.html (last visited Dec. 1, 2019) [https://perma.cc/G84ENV4X].

129. 42 U.S.C. § 2000e-4 (2019).

130. $I d$.

131. See 42 U.S.C. $\S 2000 \mathrm{e}-5$ (2019).

132. McDonnell Douglas Corp. v. Green, 411 U.S. 792, 802 (1973).

133. 42 U.S.C. $\S 2000$ e-5 (2019); Front pay describes a damage award that makes employees 
only to wage discrimination but also to discrimination in hiring practices, firing, and promotions. ${ }^{134}$ Title VII also does not just apply to sex discrimination like the Equal Pay Act. ${ }^{135}$ Title VII can be used by anyone who is in a protected class including race, religion, sex, and national origin. ${ }^{136}$

The first barrier a plaintiff faces when filing a Title VII claim for equal pay is filing with the EEOC. The EEOC will notify the employer of the claim and begin their own investigation into the complaint. ${ }^{137}$ Aggrieved employees must file a claim with the EEOC within 180 days of the discrimination. ${ }^{138}$ The EEOC's own website states that it is complicated trying to figure out how much time an employee has to file. ${ }^{139}$ For example, in Rallins v. Ohio State University, a coach's sex discrimination claims were dismissed because she did not file her claim within the required time limit. ${ }^{140}$ If the agency that is in charge of these claims thinks it's complicated, the employees certainly are at a disadvantage when it comes to filing within the time limit.

Some female sports professionals experience a difficult time proving who their employer is when multiple agencies/employers partake in planning and hosting a sporting event. For example, in Covington v. Int'l Ass' $n$ of Approved Basketball Officials, a female official sued four organizations for employment discrimination on the grounds that she was not assigned to officiate male basketball games because she was a woman. ${ }^{141}$ The district court originally dismissed her claim stating that Covington, the female official, did not adequately show she was employed by these various organizations. ${ }^{142}$ Luckily for Covington, the appellate court overruled the district court for three of the accused

whole by awarding them pay during the time the suit is underway and until nondiscriminatory placement is found for the victim. Front Pay. EQuAl EMPLOYMENT OPPORTUNITy COMMISSION, https://www.eeoc.gov/federal/digest/xi-7-4.cfm (last visited Dec. 14, 2019) [https://perma.cc/NDW2-X6Y9]; see also Albermarle Paper Co. v. Moody, 422 U.S. 405, 419-20 (1975) (holding that Title VII has a make whole purpose that allows employees to sue for backpay to encourage the public policy arguments by discouraging employers from discriminating. Backpay is pay that the employees earned but did not receive because of their discriminatory pay).

134. Know Your Rights: Title VII of the Civil Rights Act of 1964, AAUW, https://www.aauw. org/what-we-do/legal-resources/know-your-rights-at-work/title-vii/ (last visited Dec. 14, 2019) [https://perma.cc/7CS5-FFF6].

135. 42 U.S.C. $\$ 2000 \mathrm{e}-2$ (2019).

136. Id.

137. Confidentiality, U.S. Equal EMPLOYMent OpPortunity COMmission https://www.eeoc. gov/employees/confidentiality.cfm (last visited Dec. 1, 2019) [https://perma.cc/HR94-W58Q].

138. Id.

139. Id.

140. Rallins v. Ohio State Univ., 191 F. Supp. 2d 920, 927 (S.D. Ohio 2002); see also Minor v. Northville Pub. Sch., 605 F. Supp. 1185 (E.D. Mich. 1985).

141. Covington v. Int'1 Ass'n of Approved Basketball Officials, 710 F.3d 114, 117 (3d Cir. 2013).

142. Id. 
employers but did dismiss the claim against one employer. ${ }^{143}$ As this case shows, some females who work in the sports industry have a difficult time proving that the multiple associations responsible for organizing sporting events are their employers. Professional athletes could face similar issues when determining whether they work for the clubs individually or the governing body of the sport or both.

Another issue employees face with pay discrimination cases under Title VII is proving the employer intentionally discriminated against the employee when trying to demonstrate disparate treatment. ${ }^{144}$ Plaintiffs can claim either disparate impact or disparate treatment under Title VII. ${ }^{145}$ Disparate impact applies when an employer's policy appears neutral but in practice it detrimentally affects one group. ${ }^{146}$ Disparate treatment, on the other hand, requires proof of intentional discrimination to show the employer knew and was trying to exclude a certain group of employees. ${ }^{147}$

Under disparate impact theory, plaintiffs sometimes have a difficult time finding a specific policy or practice that is the cause of their discrimination as some employers operate without written or formal policies and courts have been strict in interpreting what constitutes a policy or practice. ${ }^{148}$ This presents a major issue for plaintiffs suing under Title VII and is why many plaintiffs seek to prove disparate treatment and intentional discrimination instead.

Intentional discrimination can be shown through either (1) discrimination animus by direct evidence or (2) by an indirect or inferential method of proof. ${ }^{149}$ The plaintiff has the burden of proving intent, but the employer often holds all of the information necessary to make this claim. In Ortiz v. Werner Enters., Inc., the 7th Circuit clarified the issue of direct and indirect evidence stating that all relevant evidence should be considered together (no matter which group the

143. Id. at 120 .

144. See Dewitt v. Mecklenburg Cty., 73 F. Supp. 2d 589 (W.D.N.C. 1999) (granting summary judgement in favor of defendant because plaintiff failed to prove discriminatory animus).

145. Heckman, supra note 89, at 441. See also Wambheim v. J.C. Penny Co., 705 F.2d 1492, 1494 (9th Cir. 1983) (The Supreme Court has not explicitly decided that disparate impact applies to compensation discrimination under Title VII. However, many courts have applied disparate impact analysis to these cases and believe the Supreme Court's decision in City of Los Angeles Department of Water \& Power v. Manhart, suggests that the Court would do the same. City of Los Angeles Department of Water \& Power v. Manhart, 435 U.S. 702).

146. Griggs v. Duke Power Co., 401 U.S. 424, 430 (1971).

147. Tex. Dep't of Cmty. Affairs v. Burdine, 450 U.S. 248, 253 (1981).

148. Wards Cove Packing Co. v. Atonio, 490 U.S. 642, 657 (1989); see also American Federation of State, etc. v. Washington, 770 F.2d 1401, 1405 (9th Cir. 1985) (Ninth Circuit overturned trial court and ruled that a compensation system that is determined by market forces does not constitute a practice under disparate impact theory. "Disparate impact analysis is confined to cases which challenge a specific, clearly delineated employment practice applied at a single point in the job selection process.").

149. Ortiz v. Werner Enters., Inc., 834 F.3d 760, 763 (7th Cir. 2016). 
evidence belonged in) when deciding whether there is enough evidence for a reasonable factfinder to conclude discrimination led to the adverse employment action. ${ }^{150}$

Taking another look at the United States' Women's National Soccer Team's EEOC claim, the players do not argue intentional discrimination. While the players offer a lot of proof that they deserve to be paid equal, if not better, than the male team because they are more successful and generate more revenue, the players do not offer evidence that the United States Soccer Federation intentionally chose to pay them less because of their gender. Perhaps the USSF's intention could be inferred based on the heavy evidence the Women's National Team presents, but this is unclear. Proving intent would certainly be an issue for the women's soccer team if they choose to litigate their case under Title VII. Additionally, the women do not offer a specific policy or practice that is the cause of their treatment. Because of this, the athletes likely would not have a disparate impact claim.

Title VII is not successful in ending pay discrimination or gender discrimination in general. Recent reports found that only two percent of plaintiffs using Title VII win gender discrimination cases at trial, this includes pay discrimination cases and sexual harassment cases. ${ }^{151}$ Shockingly, less than one percent of employees who believe they were discriminated against actually file charges with the EEOC. ${ }^{152}$

Employees are not filing these claims with the EEOC demonstrating a possible lack of trust and results in the legal process. Jacob Small, an attorney for employees filing discrimination lawsuits, stated, "So many people realize it's just easier for them to move on or to take a very small settlement that doesn't compensate them for the harm they've actually suffered." 153 Considering only fifteen percent of EEOC charges result in lawsuits, employees are not wrong in thinking they will not see results that make it worth filing the claim. ${ }^{154}$ The founder of the Federal Employee Legal Services Center, Rosemary Dettling, said, "I have some cases that have sat on judges' desks for five years with no hearing date in sight." " 55 Some of these statistics could be a result of the EEOC being understaffed and incapable of handling the caseload. Nevertheless, these statistics demonstrate why there have not been any recent gains in reducing the

150. Id. at 765 (This particular view about evidence is only applicable in the seventh circuit currently).

151. Michele Weldon, It's Everywhere: In Employment Discrimination, the Law Usually Wins, Not You, HufFington Post (Oct. 8, 2017), https://www.huffingtonpost.com/entry/its-everywherein-employment-discrimination-the_us_59da496ae4b08ce873a8cefa [https://perma.cc/WSM2GB95].

152. Id.

153. Juliet Linderman, At the EEOC, Harassment Cases Can Languish For Years, FederAL Times (Apr. 9, 2018), https://www.federaltimes.com/federal-oversight/watchdogs/2018/04/09/atthe-eeoc-harassment-cases-can-languish-for-years/ [https://perma.cc/K54V-4N28].

154. Weldon, supra note 151.

155. Linderman, supra note 153. 
equal pay gap in the United States.

Title VII and the Equal Pay Act are ineffective in improving gender pay equality for women in general and in professional sports. The lack of claims formally filed, yet the increasing media attention female athletes are giving the gender pay issue, points to athletes' belief that the laws are not the best way for them to make strides in gaining pay equality. These laws fail to account for the discriminatory practices already in place that affect the ability of female athletes and female sports to raise revenue, generate ticket sales, and gain viewers and fans. The United States needs to enact new, more proactive laws to address gender pay discrimination that do not put such heavy and demanding requirements on the employees making the claims. Iceland's new gender pay legislation offers an insightful and progressive response to the issue of gender pay inequality.

\section{ICELAND LEADS THE WAY IN CLOSING THE GENDER PAY GAP}

\section{A. Iceland's History of Gender Equality}

Iceland is leading the way in gender equality laws and regulations world-wide despite being a small island in the North Atlantic. Iceland is known for having a highly regarded health care and educational system and widely available internet. ${ }^{156}$ Geographically, Iceland is made up of both active volcanoes and glaciers. ${ }^{157}$ Summer days in this country consist of 24-hours of sunshine and winter days offer only a few hours with the sun. ${ }^{158}$ The Icelandic language is widely used throughout the country and this culture has a strong literary tradition. ${ }^{159}$

Iceland has led the world in gender equality for decades. Iceland's first female president elected in 1980 was the first female democratically elected head of state in the world. ${ }^{160}$ In fact, the women's movement in Iceland started as early as the 1850's when masses of Iceland's population was migrating to North America. ${ }^{161}$ During this time, women gained the same inheritance rights as men and the first women's association was founded. ${ }^{162}$ In the 1920 's, women were

156. About Iceland, INSPIRED BY ICELAND, https://www.inspiredbyiceland.com/about-iceland (last visited Feb. 16, 2019) [https://perma.cc/R8ZJ-4HTF]; see also Michael Chapman, Gender Equality in Iceland, GUIDE TO ICELAND, https:/guidetoiceland.is/history-culture/gender-equality-iniceland (last visited Feb. 16, 2019) [https://perma.cc/7Q6L-KCGT] (In Iceland, 66\% of university graduates are women).

157. About Iceland, supra note 156.

158. Id.

159. Id.

160. The Center for Gender Equality Iceland, Information on Gender Equality Issues in Iceland (2017) (ICE.).

161. Id. at 4 .

162. Id. 
given the same rights as men in marriages and in regard to their children. ${ }^{163}$ In 1961, the Icelandic Parliament approved a law addressing the gender wage gap. ${ }^{164}$ In the 1970's, the "Red Stockings" movement, inspired by feminism around the world, became key in raising awareness on gender equality issues in this country. ${ }^{165}$ In the 1990's, the Centre for Women's and Gender Studies was founded and began studying and advancing gender issues across the nation. ${ }^{166}$ Finally, in the 2000's, men's groups were formed to help end rape and genderbased violence. ${ }^{167}$ Iceland is recognized for giving full rights to gay and lesbian people, banning strip-dancing clubs, creating laws that require corporation boards have a minimum quota of $40 \%$ women, and having both maternity and paternity leave. ${ }^{168}$

Iceland has a population of about 334,000 people. ${ }^{169}$ Women make up $49 \%$ of the total population. ${ }^{170}$ Iceland's parliament is 50\% women. ${ }^{171}$ Comparatively, the United States Congress has only $20 \%$ representation of women despite the population being about $50 \%$ female nationally. ${ }^{172}$ Lawmakers in Iceland are equally female and male, allowing the views of the historically inferior population (women) to be heard in the government.

In 2017, Iceland elected Katrin Jakobsottir as Prime Minister of the country, making her the second female leader. ${ }^{173}$ The United States has never had a female president. The World Economic Forum and other international comparisons have consistently ranked Iceland as the global leader for gender equality. ${ }^{174}$ The

163. Id. at 5 .

164. Id.

165. Id.

166. The Center for Gender Equality Iceland, Information on Gender Equality Issues in Iceland (2017) (ICE) at 6.

167. $I d$.

168. Id.

169. Tanya Tarr, How Icelandic Women Really Feel about the New Equal Pay Law, ForBES (Jan. 8, 2018), https://www.forbes.com/sites/tanyatarr/2018/01/08/how-icelandic-women-reallyfeel-about-the-new-equal-pay-law/\#24479194f13d [https://perma.cc/P9PD-PWB4].

170. Population by Sex and Age 1841-2018, StATistics ICELAnd, http://px.hagstofa.is/pxen/pxweb/en/Ibuar/Ibuar_mannfjoldi_1_yfirlit_yfirlit_mannfjolda/M AN00101.px/?rxid=1 bacdab8-e84d-4183-a189-62fc077949cd (follow Sex: total, Age: total, Year: 2019) (last visited Feb. 16, 2019) [https://perma.cc/E8LJ-Q5XH].

171. Carter, supra note 7.

172. Women in Congress 2018, Center for American Women in Politics (2018), http://www.cawp.rutgers.edu/women-us-congress-2018 (last visited Dec. 1, 2019) [https://perma.cc/M9K8-ZSTC].

173. Tarr, supra note 169.

174. New Icelandic Law on Equal Pay Certification Entered into Force on January 1, 2018, Ministry OF SOCIAL AFFAIRS (Jan. 4, 2018), https://www.government.is/news/article/?newsid= 39d0a25d-f139-11e7-9423-005056bc530c [https://perma.cc/LKE7-5YAW]; see also Tarr, supra note 169 and Global Gender Gap Report 2016, supra note 8. 
United States was ranked $45^{\text {th }}$ out of 144 countries in this same study. ${ }^{175}$

Iceland won these accolades because the Icelandic Act on Equal Status and Equal Rights of Women and Men created a gender equality council of eleven members, created a gender equality forum that discusses gender equality issues and presents developments, gives municipalities power to appoint gender committees, and gives ministries the power to have expert gender equality representatives. ${ }^{176}$

Finally, the gender pay gap in Iceland is estimated to be about $10 \% .{ }^{177}$ This represents one of the lowest gender pay gaps in the world. ${ }^{178}$ Iceland's own government researches and studies the pay inequality gap to determine if their work is effective and what further legislation is needed. ${ }^{179}$ Due to Iceland's vast history of gender equality reform and its progressive and innovative regulations, the United States should look to Iceland when drafting the overdue changes to the Equal Pay Act and Title VII of the Civil Rights Act.

Sports are very popular in Iceland. Iceland has both professional and amateur athletes. ${ }^{180}$ The most popular sports in this country are soccer and handball. ${ }^{181}$ The women's national soccer team is ranked nineteenth in the world, while the men's team is ranked twenty-second. ${ }^{182}$ Icelandic athletes regularly compete in the Olympics and other world tournaments including the FIFA World Cup. ${ }^{183}$ In 2018, the Icelandic Men's World Cup team qualified for a spot to compete in the FIFA Men's World Cup making them the least populous nation to ever play in this tournament. ${ }^{184}$ Female athletes receive a lot of media coverage in Iceland and have numerous supporters consisting of both individuals and companies that financially support their teams. ${ }^{185}$

Iceland values training children to play sports. Iceland offers financial support to families allowing more children to play organized sports. ${ }^{186}$ There are

175. Global Gender Gap Report 2016, supra note 8.

176. Act on Equal Status and Equal Rights of Women and Men, 2008 (Act No. 10/2008) (Ice.).

177. The Gender Pay Gap Narrows, Statistics ICELAnd (Mar. 7, 2018), https://www. statice.is/publications/news-archive/wages-and-income/analysis-on-gender-pay-gap-2008-2016/ [https://perma.cc/WP8A-89KE].

178. Global Gender Gap Report 2016, supra note 8.

179. The Gender Pay Gap Narrows, supra note 177.

180. Sports in Iceland, INSPIRED BY ICELAND, https://www.iceland.is/press/press--mediakit/sports-in-iceland/ (last visited Dec. 14, 2019) [https://perma.cc/8RWT-JFSK].

181. Id.

182. Id.

183. Id.

184. John Leicester, One Iceland Player Prepared to Defend Lionel Messi by Working as a Salt-Packer at a Warehouse, Boston GlOBE (June 15, 2018), https://www.boston.com/ sports/soccer/2018/06/15/iceland-salt-packer-messi [https://perma.cc/ZN2H-NXRY].

185. Chapman, supra note 156.

186. Sports in Iceland, supra note 180. 
also incentives for people who lead a healthy and active lifestyle. ${ }^{187}$

Iceland's ability to effectively close the gender pay gap and promote sports equally for men and women make them an ideal country to study. Iceland's new equal pay legislation is the most aggressive legislation in the world promoting gender pay equality.

\section{B. Iceland's New Equal Pay Law}

Iceland's new equal pay act is described as one of the toughest equal pay laws in the world. The law states, "The aim of this act is to establish and maintain equal status and opportunity for women and men, and thus promote gender equality in all spheres of the society."188 This new law is an amendment to the Gender Equality Act of 2008. ${ }^{189}$ Icelandic leaders hope these new, rigorous regulations will end the gender pay gap completely in their country by as early as $2022 .{ }^{190}$

The revised portion of the Gender Equality Act requires companies to selfassess in order to determine if they are paying all genders equally. ${ }^{191}$ Article 19 of this act was modified and now states, "Women and men working for the same employer shall be paid equal wages and enjoy equal terms of employment for the same job or jobs of equal value." 192 The distinction is jobs of equal value, which does not always mean that two employees must have the exact same job and job title to be eligible for equal pay. This act also states that employees shall receive the same terms of employment, thus highlighting that job benefits should be the same for those employees with jobs of equal value. ${ }^{193}$

This law breaks the stigma on not discussing salary, pay, and benefits. The act specifically allows workers to disclose their wage terms, thus giving employees the opportunity to learn by talking with each other about what benefits and pay they receive compared to other employees. ${ }^{194}$ This alone will help employees to more easily determine when they are being discriminated against. There will be more transparency in the pay process, and therefore, more accountability for companies that practice wage discrimination.

The new law also requires that companies proactively work toward gender pay equality. Companies with 25 or more employees are required to obtain equal

187. Id.

188. Act on Equal Status and Equal Rights of Women and Men, 2008 (Act No. 10/2008) (Ice.).

189. New Icelandic Law on Equal Pay Certification Entered into Force on January 1, 2018, supra note 174.

190. Id.

191. Id.

192. Act on Equal Status and Equal Rights of Women and Men, 2008 (Act No. 10/2008) (Ice.).

193. Id.

194. Id. 
pay certification from the government or an approved agency. ${ }^{195}$ The certification process looks at the company's policies, classification of jobs, and value given to these jobs to determine if the company has an objective pay structure. ${ }^{196}$ Companies are required to value their jobs based on responsibilities and tasks alone, not based on who currently resides in that position. ${ }^{197}$

This law is proactive instead of being reactive like the United States' equal pay laws. Iceland is seeking to stop gender discrimination before it starts by making companies look at the positions they offer and value those positions based on the responsibilities and work involved. ${ }^{198}$ Similar to the United States, most countries simply try to act after discrimination has occurred and a party is injured. Iceland's revolutionary law attempts to stop discrimination before there is harm done to employees.

Iceland's law also puts the burden on the employer to make sure they are paying different genders equally instead of placing the burden on the employee to determine if the inequality exists then sue. ${ }^{199}$ This is ground-breaking for equal pay laws because most require the employee to have some proof that the pay inequality exists, thus the burden is on the employee. However, employees often do not have the information needed to make these claims, such as the salary of another employee to compare or proof of intentional discrimination by the employer. Iceland's law eliminates these issues because salaries are required to be made available to employees and the discrimination does not have to be intentional for employees to have successful claims against their employers.

Finally, if a company does not receive certification or is in violation of the act, the Centre for Gender Equality can impose per diem fines. ${ }^{200}$ The certification must be renewed every three years to ensure that companies are maintaining their policies. ${ }^{201}$ It seems that Iceland is planning on using these regulations long term, even when gender pay equality is reached, to maintain fairness.

Iceland's government notes, "The new legislation makes Iceland the first country in the world to require employers to obtain certification on the basis of requirements of a management requirement standard to prove they offer equal pay for work of equal value regardless of gender." ${ }^{202}$ The government stated that this

195. Id.

196. New Icelandic Law on Equal Pay Certification Entered into Force on January 1, 2018, supra note 174.

197. Id.

198. Act on Equal Status and Equal Rights of Women and Men, 2008 (Act No. 10/2008) (Ice.).

199. New Icelandic Law on Equal Pay Certification Entered into Force on January 1, 2018 , supra note 174.

200. Id.

201. Id.

202. Questions and Answers on Equal Pay Certification, Ministry of Social AfFairs (Jan. 30, 2018), https://www.government.is/news/article/2018/01/30/Questions-and-Answers-on-equal- 
law was translated in various languages specifically so other countries could impose similar regulations and adopt the law. ${ }^{203}$

There are currently no defenses in the new equal pay law that employers can automatically assert to justify pay differentials. "Companies must prove to an external auditor any wage difference between roles of equal value is justified, otherwise discrimination is assumed." 204 As this law continues to take effect and litigation arises, it will be interesting to see if any defenses begin to develop in the courts, such as demanding the jobs be of equal value extremely strictly or determining what is a justified reason for a difference in pay. Iceland has dedicated a vast amount of time and resources to close the gender pay gap. Therefore, it is unlikely that judges will let the employers drive litigation by asserting defenses. Already, a chef at Iceland's National Land Survey received a 4.5 percent pay increase after her bosses discovered she was underpaid compared to the rest of the chefs employed. ${ }^{205}$

Iceland's certification process is an innovative approach to gender pay discrimination. Potential employees will be able to see whether employers have violations and make more informed decisions about their employment. This law takes the burden off the employees and properly puts the burden on the employers who have more knowledge and information to determine if gender equality issues exist. Because this law was enacted in January 2018, the full effects of the new regulations are not yet clear. Many companies have been given a year or more to become certified because of the lengthy process. ${ }^{206}$ Despite the outcome of this law being unknown for now, there are still many things the United States can learn from Iceland's legislation about prioritizing fairness and equality for employees, over the privacy rights of employers.

\section{WHAT THE UNITED STATES SHOULD CHANGE BASED ON ICELAND'S NEW REGULATIONS}

The current laws are not working to reduce gender discrimination in the United States nationally, or specifically for female athletes. Iceland's gender gap is at least half of the United States', which demonstrates their laws are working in ways the U.S.'s laws are not. ${ }^{207}$ First, this section will address why the United

pay-certification/ [https://perma.cc/3FNE-GEBK].

203. New Icelandic Law on Equal Pay Certification Entered into Force on January 1, 2018 , supra note 174.

204. Nick Rigillo and Ragnhildur Sigurdardottir, Their Jobs Haven't Changed, But Iceland's Women Are Getting Raises, BloOMBeRG (July 8, 2018), https://www.bloomberg.com/news/ articles/2018-07-09/their-jobs-haven-t-changed-but-iceland-s-women-are-getting-raises [https://perma.cc/7BBS-V3C7].

205. Id.

206. New Icelandic Law on Equal Pay Certification Entered into Force on January 1, 2018, supra note 174.

207. The Gender Pay Gap Narrows, supra note 177; see also Global Gender Gap Report 2016, supra note 8 . 
States is not likely to adopt Iceland's new law in its entirety. Next, this section will focus on the changes the US can make, including making pay scales public, getting rid of the affirmative defenses in the EPA and intentional discrimination in Title VII, and finally, doing further studies about the gender wage gap and properly funding the Equal Employment Opportunity Commission.

Professional athletes are not using the legal system to gain equal pay. Instead they are using their star power, voices, and threats of boycotts to force their governing bodies into action. ${ }^{208}$ This demonstrates that women do not trust the legal system to protect them against gender inequality. This is unacceptable. The EEOC claim filed by the Women's National Team was the first legal action of its kind taken by professional athletes to fight the gender pay gap. ${ }^{209}$ The legal system is supposed to be a catalyst for change that allows inferior groups to gain equality. However, female athletes are turning to the media to gain support and pressure their organizations to make changes. While this was effective for both the women's soccer and hockey teams, lesser known athletes and women in general who do not have a big stage to share their experiences will not be protected by this method of action. These reasons are why the law must be strengthened to support all levels of female athletes.

\section{A. Why the United States Will Not Adopt Iceland's New Law in Its Entirety}

It is very unlikely that the U.S. will adopt Iceland's new legislation in its entirety. First, the U.S. has a population that is exponentially larger than Iceland's. This means that requiring every one of the millions of companies in the country to obtain equal pay certification will take a substantial amount of money, people, and time. This task may be more effective in a cost/benefit analysis for smaller countries.

Additionally, Iceland favors more government intervention in private and business affairs than the United States traditionally accepts. Iceland, along with the other Nordic countries, is often considered a social democracy. ${ }^{210}$ In other words, Iceland allows more government intervention in the market than traditional capitalists would support. Iceland has regulated everything from health care to company benefits for decades. ${ }^{211}$ The U.S., on the other hand, traditionally likes to let the market work out these issues as a capitalist driven society. For these reasons, it is very unlikely that the United States will adopt Iceland's equal pay law in its entirety since the law heavily monitors the internal

208. US Women's Hockey: From Fighting for Better Pay to Fighting for Gold, CNN (Feb. 21, 2018), https://money.cnn.com/2018/02/21/news/us-womens-hockey-olympics/index.html [https://perma.cc/H47K-6ACW].

209. Santhanam, supra note 3.

210. Geoffrey M. Hodgson, What the World Can Learn About Equality From the Nordic Model, The CONVERSATION (July 30, 2018), https://theconversation.com/what-the-world-can-learnabout-equality-from-the-nordic-model-99797 [https://perma.cc/E4FV-MG9C].

211. About Iceland, supra note 156; see also Chapman, supra note 156. 
ways companies manage themselves. However, the U.S. can still look to Iceland's example to determine ways to make it easier for women to sue and be successful in equal pay lawsuits.

Another notable difference between the United States and Iceland is the role the law plays in these countries. Iceland is a civil law country. ${ }^{212}$ Meanwhile, the United States operates as a common law society. This distinction means that Iceland's legal system is characterized by laws and statutes. ${ }^{213}$ The main sources of Icelandic law come from the Constitution, statutory legislation, and regulatory statutes. ${ }^{214}$ Civil law systems do not emphasize the use of precedent and prior case law nearly as much as common law countries. ${ }^{215}$ Although civil law systems do not depend entirely on legislation, the legislation plays a vital role. ${ }^{216}$ This difference is another reason why Iceland more extensively regulates the market through laws and legislation.

\section{B. Public Pay Scales}

The United States should make a new law that companies cannot include wage privacy agreements in employment contracts. The U.S. government already posts the wages of all of their employees, but the government needs to encourage, better yet, demand private companies do the same. ${ }^{217}$ Forgoing the taboo of speaking about wages and benefits will help women to know when they are being discriminated against sooner. Also, it will help women to more easily gain evidence when they are being underpaid due to gender discrimination. A law that makes salaries and benefits public forces companies to be more transparent and more fair in their wage and salary structures. Making wages public could help the issue of timely filing under the Equal Pay Act and Title VII. Many women miss their opportunity to file because they do not realize they were discriminated against until it is too late. Public pay scales could help solve this issue.

Many sports professionals' salaries are available to the public. For example, public universities are required to reveal the salaries of all coaches at their institutions. ${ }^{218}$ Reports like the Forbes Top 100 Paid Professional Athletes detail the total earnings of professional athletes. ${ }^{219}$ However, contract deals like those

212. The Legal System in Iceland, ICELANDiC FinANCIAL SERVICES ASSOCIATION, https://sff.is/ en/legislation/legal-system-iceland (last visited Dec. 1, 2019) [https://perma.cc/UT9W-R5UD].

213. Id.

214. Id.

215. Civil Law, The Wolters Kluwer Bouvier Law Dictionary (Vol. I 2012).

216. $I d$.

217. Search Federal Employee Salaries, FedS DATA CENTER, https://www.fedsdatacenter. com/federal-pay-rates/index.php? $=2017 \& \mathrm{n}=$ bepko\&l $=\& \mathrm{a}=\& \mathrm{o}=($ last visited Dec.1, 2019) [https://perma.cc/XEG9-CS3U].

218. Freedom of Information Act, 5 USC § 552 (1966); see also IND. CODE § 5-14-3-1 (States have created their own freedom of information laws. These laws include public universities that "receive public funds through an agreement with the state. .." IND. CODE § 5-14-3-2.1).

219. Elsesser, supra note 14. 
between the Women's National Soccer Team and the United States Soccer Federation or the Women's National Hockey Team and USA Hockey are often kept private. Making these deals public would hold the organizations more accountable, especially in highly publicized cases like the Women's National Soccer Team.

If contract terms are made public, other organizations might wish to follow these examples in creating better terms for their female athletes. Collective bargaining agreements should be made public for the same reasons. There is little harm in getting rid of the stigma of talking about benefits and salaries and conversely, more transparency can be gained. Therefore, the U.S. should follow Iceland's lead and make it illegal to have wage privacy agreements. However, making wages public alone is not enough to combat gender wage discrimination.

\section{No More Affirmative Defenses in the Equal Pay Act and No Requirement of Intentional Discrimination in Title VII}

The United States needs to update the Equal Pay Act and get rid of the affirmative defenses that support the employers in their discrimination. ${ }^{220}$ Additionally, the component of Title VII that requires employees prove the discrimination was intentional should be removed. ${ }^{221}$ Iceland does not include affirmative defenses in their act or require that employees show intentional discrimination. Instead, Iceland puts the burden of proof and the responsibility on the employers. The U.S.'s laws have too heavy of a burden on the employees to produce evidence they do not have and sometimes cannot get. Lawmakers should place the burden on employers because they have a monopoly on the information necessary to bring these lawsuits.

Courts should interpret the Equal Pay Act and Title VII differently. When analyzing these cases in court, instead of focusing on whether the pay scale is a merit system or quantity/quality system, the court should focus on whether the job responsibilities and duties are comparable regardless of the structure of the pay scale.

The court tends to mandate the jobs be alike so strenuously that some women cannot find appropriate comparators. Conversely, Iceland does not focus on job titles but instead focuses on the obligations that the job requires. Women in less traditional jobs will be more likely to find male employees to compare their salaries with if this approach is taken. Female athletes occupy the nontraditional career category. By focusing on the responsibilities of the athletes, for example the responsibility to be fit, win games, train, and attend media events, it is clear that both male and female athletes have the same responsibilities despite being involved in different clubs and organizations.

Courts need to follow Judge Reinhardt reasoning in his opinion in Rizo $v$. Yovino that limits employers' ability to use these vast defenses, like the any factor

220. Facts about Equal Pay and Compensation Discrimination, supra note 75.

221. Ortiz v. Werner Enters., Inc., 834 F.3d 760 at 763. 
other than sex defense. ${ }^{222}$ More decisions with this reasoning would be helpful in allowing plaintiffs' claims to succeed. Updating the Equal Pay Act and Title VII to show that jobs need only be similar in duties and getting rid of the affirmative defenses and the requirement for intentional discrimination would allow more women to successfully sue under these laws.

\section{Study and Analyze Gender Discrimination Issues and Properly Fund the Equal Employment Opportunity Commission}

Finally, the United States should follow Iceland's many examples of the ways they monitor and advance gender equality issues, including by studying gender inequality, appointing experts to government positions, and having gender equality committees in both the central government and municipalities. ${ }^{223}$ Iceland sets an example that demonstrates that gender equality issues are important to the government and the people. The government does numerous studies every year, files reports with data about how new laws and regulations have affected change, and is not afraid to implement new, progressive regulations to close the wage gap. ${ }^{224}$

The United States needs to prioritize this issue and give more congressional attention to wage discrimination since it effects about $50 \%$ of the population. ${ }^{225}$ One way this could be improved is by having a congressional body that equally represents the male and female populations in the US. In other words, more women need to be elected in Congress to have equal representation. ${ }^{226}$ This change would likely help wage discrimination become an important topic because more people affected by the discrimination would be in Congress.

The United States should look for ways to be more proactive in addressing wage discrimination issues and not just the reactive nature of the current laws. Setting up a program that allows companies to voluntarily submit to pay equality analysis and allowing certification for those companies that do not discriminate is one way to be proactive. Although not all companies would want to undergo this process, women would be able to recognize companies that not only say they value fairness and equality, but companies that actually practice these values. If voluntary certification of companies becomes popular, then some companies

222. Rizo v. Yovino, 887 F.3d 453, at 453 (Overruled due to Judge Reinhardt's death prior to the decision being filed in Yovino v. Rizo, 139 S. Ct. 706, 710 (2019).).

223. Act on Equal Status and Equal Rights of Women and Men, 2008 (Act No. 10/2008) (Ice.).

224. Id.

225. Quick Facts, US CENSUS BUREAU, https://www.census.gov/quickfacts/fact/table/ US/PST045218 (follow Select a fact - population estimates July 1, 2018) (last visited Dec. 1, 2019) [https://perma.cc/RNH8-V4TC].

226. Drew Desilver, A Record Number of Women Will Be Serving in the New Congress, Pew RESEARCH CENTER (Dec. 18, 2018), https://www.pewresearch.org/fact-tank/2018/12/18/recordnumber-women-in-congress/ [https://perma.cc/LNC2-CKGB] (There are currently 25 women in the Senate and 35 women in the House.). 
could feel shamed into submitting to the process because not doing so would make it appear like the companies are discriminating or hiding behind prejudices.

The United States needs to better equip the Equal Employment Opportunity Commission to handle these cases, similar to the way Iceland prioritizes the work of the Centre for Women's and Gender Studies. The Equal Employment Opportunity Commission works on cases involving sexual harassment, equal pay, and discrimination based on sex, race, or national origin. Their work covers a vast array of issues and results in a congested workload. The EEOC does not have enough money, people, or judges to handle the amount of issues they represent.

This is especially true given the increased attention sexual harassment has received in the media due to the "\#MeToo" movement. ${ }^{227}$ Cathy Harris, an employment attorney, stated, "I don't think there's more discrimination; I think people are just encouraged to do something about it now."228 The U.S. government needs to recognize this change in society and properly fund and staff the EEOC to address these issues. A study in 2017 revealed the average wait time for a complaint filed with the EEOC was 295 days. ${ }^{229}$ When employees have to wait nearly a year to get their discrimination claims investigated and heard, evidence tends to become sparse and morale for victims tends to dissipate.

The EEOC's caseload is so heavily burdened that the commission ranks cases based on the likelihood of their success and the evidence that is immediately available (without further investigation). ${ }^{230}$ This means that the outcome of the EEOC's cases is likely inflated because they are more frequently pursuing cases they know they can win with the least amount of effort and time needed by their staff. All of these issues can be fixed by expanding the EEOC's staff and budget. The U.S. needs to recognize the importance of the issues the EEOC works on and give the organization a chance to make a difference.

Iceland sets a great example demonstrating their prioritization of gender pay equality by creating laws that proactively address this issue. The United States should follow this example because Iceland leads the world in identifying and resolving these issues.

\section{CONCLUSION}

Female athletes face a gender wage gap in almost all sports. ${ }^{231}$ The recent cases of the Women's National Soccer Team and the Women's National Hockey Team demonstrate that the law is not the best way for female athletes to voice their equal pay complaints. The athletes used their star power to bring attention to the unequal pay they receive compared to their male counterparts. But not all

227. Linderman, supra note 153.

228. $I d$.

229. $I d$.

230. $I d$.

231. Spitz, supra note 15. 
athletes have the luxury of being able to be heard by millions. The Equal Pay Act and Title VII need to be updated to support plaintiffs, instead of deterring their claims, so women will be more inclined to sue.

The U.S. should look to Iceland, one of the leading countries that has minimized the gender pay gap, as an example of the potential ways legislation can rectify this issue. ${ }^{232}$ Iceland's new legislation that requires companies to obtain gender equality certification is not likely in the near future for the U.S. However, there are many other aspects of this law that would be easily achievable steps in the right direction. These aspects include funding more studies about the equal pay gap and the EEOC, appointing experts to committees, demanding wage transparency, and appointing gender inequality committees to both the federal and municipal governments. ${ }^{233}$ Additionally, the United States should update the Equal Pay Act and remove the defenses that allow employers to justify their discriminatory pay. Title VII should be updated and the requirement to prove discriminatory intent should be removed.

The U.S. government also needs to properly fund the Equal Employment Opportunity Commission in order to give this organization more staff members and more money to address the exponentially growing number of discrimination cases being filed. All of these changes would make it easier and more effective for female athletes to file wage discrimination claims in court.

232. The Gender Pay Gap Narrows, supra note 177.

233. Id. 